\title{
Factors Controlling Amino Acid Incorporation by Ribosomes from Krebs II Mouse Ascites-Tumour Cells
}

\author{
BY I. M. KERR,* N. COHEN AND T. S. WORK \\ National Institute for Medical Research, Mill Hill, London, N.W. 7
}

(Received 19 August 1965)

\begin{abstract}
1. A ribosome-cell sap system capable of supporting the incorporation of ${ }^{14} \mathrm{C}$-labelled amino acids into protein has been prepared from Krebs II mouse ascites-tumour cells. The requirements of this system for optimum activity and response to added messenger RNA have been investigated. One such system has been obtained for which amino acid incorporation is almost wholly dependent on the addition of suitable messenger RNA. 2. Ribosomes of widely different but predictable activities in the cell-free system have been prepared from Krebs cells pretreated in a variety of ways. The factors in the pretreatment of the cells responsible for these differences have been investigated. 3. The structural and functional properties of these different ribosome preparations and their response to exogenous messenger RNA have been examined and are discussed in the light of modern concepts of the control of protein synthesis.
\end{abstract}

Previous reports from this Laboratory have described the amino acid-incorporation activity of microsome-cell sap systems obtained from normal and EMC-virust-infected Krebs II mouse ascitestumour cells (Krebs cells). It was shown that microsomes from infected cells had a lowered intrinsic activity but that this activity increased markedly in response to added EMC-virus RNA. These experiments were taken to indicate that the m-RNA content of the microsome fraction of infected cells was below normal and that the EMC. virus RNA was capable of functioning as a replacement messenger (Kerr, Martin, Hamilton \& Work, 1962). These systems have now been further refined and a ribosome-cell sap preparation has been obtained for which amino acid incorporation is almost wholly dependent on the addition of EMCvirus RNA or polyU.

During this work it was observed that the total amino acid incorporation supported by ribosomecell sap systems from uninfected cells varied greatly according to the mode of pretreatment of the cells. Further investigation showed that these variations resulted from changes in the ribosome fraction and that, by suitably pretreating cells, ribosomes could be prepared with a variety of predictable activities.

* Present address: Department of Biochemistry, Stan. ford University, Palo Alto, Calif., U.S.A.

$\dagger$ Abbreviations: EMC virus, encephalomyocarditis virus; m-RNA, messenger RNA; s-RNA, 'soluble' or transfer RNA; TBS, tris-buffered saline; PBS, phosphate-buffered saline; polyU, polyuridylic acid.
Thus ribosomes from cells that, on isolation from mice, were rapidly washed free of ascitic fluid at $0^{\circ}$ were 2-3 times as active as those from cells washed slowly or at room temperature. Incubation in a simple buffered salts medium at $37^{\circ}$ of the cells washed at room temperature yielded ribosomes of very low activity. When, however, the preincubation was carried out in the presence of glucose, the activity of the ribosomes increased very rapidly until it reached the level of preparations from fresh cold-washed cells.

We have investigated the factors controlling this variation in ribosomal activity and the response of these different ribosome preparations to EMC-virus RNA. Our results suggest that the rate of protein synthesis in mammalian cells may be controlled by factors in addition to those concerned with the rate of $\mathrm{m}-\mathrm{RNA}$ synthesis.

\section{MATERIALS AND METHODS}

Materials. ATP, GTP and pyruvate kinase were obtained from C. F. Boehringer und Soehne G.m.b.H. (Mannheim, Germany). For use in the cell-free system ATP and GTP solutions of the required molarity were adjusted to $\mathrm{pH} 6 \cdot 5$ 7.0 with $\mathrm{N}-\mathrm{KOH}$. Phosphoenolpyruvate, supplied as the silver-barium salt (C. F. Boehringer und Soehne G.m.b.H.), was converted into the potassium salt, and solutions of the required molarity were adjusted to $\mathrm{pH6 \cdot 5-7 \cdot 5}$ with $\mathrm{N}$ $\mathrm{KOH}$, the total concentration of $\mathrm{K}^{+}$in the solution being taken into account in the amino acid-incorporation assay. $\beta$-Mercaptoethanol (L. Light and Co. Ltd., Colnbrook, Bucks.) was redistilled and made up as a $0.5 \mathrm{M}$ solution with 
deionized water and adjusted to $\mathrm{pH6-7}$ with $\mathrm{N}-\mathrm{KOH}$. These solutions were stored at $-18^{\circ}$. Actinomycin $\mathrm{D}$ was obtained from Merck and Co. Inc. (Rahway, N.J., U.S.A.), polyU from Miles Chemical Corp. (Elkhart, Ind., U.S.A.), uniformly ${ }^{14} \mathrm{C}$-labelled amino acids and $\left[1-{ }^{14} \mathrm{C}\right]$ leucine from The Radiochemical Centre (Amersham, Bucks.) and crystalline pancreatic deoxyribonuclease from the Worthington Biochemical Corp. (Freehold, N.J., U.S.A.).

Buffers and solutions. TBS contained the following (final concentrations): $\mathrm{NaCl}(146 \mathrm{~mm})$; tris buffer (acetate or chloride), pH7.8 (measured at room temperature) (35 mM). PBS contained the following (final concentrations): $\mathrm{NaCl}$ (136 mM); $\mathrm{KCl}(2.7 \mathrm{mM}) ; \mathrm{MgSO}_{4}(0.5 \mathrm{~mm}) ; \mathrm{CaCl}_{2}$ (0.9 mM); $\mathrm{KH}_{2} \mathrm{PO}_{4}$ (1.5 mM); $\mathrm{Na}_{2} \mathrm{HPO}_{4}$ (8 mM).

Earle's medium was prepared as described by Martin, Malec, Sved \& Work (1961) and contained the following (final concentrations): $\mathrm{NaCl}(117 \mathrm{~mm}) ; \mathrm{KCl}(5 \cdot 38 \mathrm{~mm})$; $\mathrm{MgSO}_{4}$ (0.8 mM); $\mathrm{CaCl}_{2}$ (1.8 mM); $\mathrm{NaH}_{2} \mathrm{PO}_{4}$ (1.2 mM); $\mathrm{NaHCO}_{3}$ (equilibrated with $\mathrm{CO}_{2}$ gas) (26 mM); glucose (11 mM; $0.2 \%$ ); benzylpenicillin (100i.u./ml.) and streptomycin- $\mathrm{CaCl}_{2}(60 \mu \mathrm{g}$./ml.) (Glaxo Laboratories Ltd., Greenford, Middlesex).

Pseudo-Earle's medium was prepared as for Earle's medium, and contained (final concentrations): $\mathrm{NaCl}$ (100 mM); $\mathrm{KCl}$ (3.7 mM); $\mathrm{CaCl}_{2}$ (1.8 mM); $\mathrm{MgSO}_{4}$ (0.8 mM); $\mathrm{Na}_{2} \mathrm{HPO}_{4}(8 \mathrm{mM}) ; \mathrm{KH}_{2} \mathrm{PO}_{4}(1.5 \mathrm{mM}) ; \mathrm{NaHCO}_{3}$ (equilibrated with $\mathrm{CO}_{2}$ gas) (26 mM); glucose (11 $\mathrm{mm}$; $0.2 \%$ ).

The following solutions were used in the preparation of the ribosome and cell-sap fractions from Krebs cells. Solution A contained (final concentrations): tris buffer, pH 7.7-7.8 (210 mM); $\mathrm{KCl}(150 \mathrm{mM}) ; \beta$-mercaptoethanol (60 mM); EDTA (6 mM); magnesium acetate $(6 \mathrm{~mm})$; sucrose $(1.5 \mathrm{M})$. Solution $\mathrm{B}$ was made by the addition of $5 \mathrm{vol}$. of 6 mM-magnesium acetate to 1 vol. of solution A. Solution C contained (final concentrations): tris buffer, $\mathrm{pH} 7 \cdot 7-7 \cdot 8$ (20 mM); $\beta$-mercaptoethanol (5 mM); EDTA (1 mM).

All solutions of EDTA (disodium salt) (Hopkin and Williams Ltd., Chadwell Heath, Essex) were adjusted to pH7.0 with KOH before use.

Estimation of protein. The protein content of ribosome and cell-sap fractions was estimated by the method of Lowry, Rosebrough, Farr \& Randall (1951), with crystalline bovine serum albumin as standard.

Propagation of Krebs cells. The origin of the cell line used and its mode of propagation intraperitoneally in mice was as described by Martin et al. (1961). Storage of stocks of cells in ampoules at $-70^{\circ}$ made it possible to carry out all experiments on cells five generations removed from an original stock (Martin et al. 1961).

Washing and preincubation of Krebs cells. On withdrawal from mice, the ascitic fluid was transferred to $50 \mathrm{ml}$. centrifuge tubes each containing one-third of their volume of the appropriate washing medium and centrifuged at $60 \mathrm{~g}$ for $8 \mathrm{~min}$. at the temperature indicated in the individual experiments. The supernatant fluid was discarded and the sedimented cells were washed twice by centrifugation as above. Incubations were carried out at $2 \times 10^{7}$ cells $/ \mathrm{ml}$, usually under semi-anaerobic conditions, i.e. large volumes of cell suspensions in relatively small (2-5 times the volume of cell suspension) stoppered flasks incubated with only gentle shaking. The washing and incubation procedures were done with sterile solutions and glassware.

Preparation of ribosome and cell-sap fractions. After cells had been harvested, washed and incubated as required by the individual experiments, they were chilled on ice and, if necessary, washed rapidly twice with ice-cold TBS to remove phosphate (a potential inhibitor in the cell-free system). The cells were then centrifuged at $2300 \mathrm{~g}$ for $3 \mathrm{~min}$. at $4^{\circ}$. In some instances the packed cells were stored at $-70^{\circ}$ before homogenization. If so, freezing and thawing were both done as rapidly as possible. The packed cells were resuspended at $0^{\circ}$ in 3 times the packed-cell volume of $6 \mathrm{~mm}$-magnesium acetate. After standing at $0^{\circ}$ for $2 \mathrm{~min}$., the cells were disrupted by about 30 strokes of a tight-fitting all-glass Dounce homogenizer. Immediately after homogenization, a volume of solution A equivalent to three-fifths the packed-cell volume was added to the homogenate, which was then centrifuged twice at $20000 \mathrm{~g}$ for $10 \mathrm{~min}$. at $0^{\circ}$, the fat layer and sediment being discarded each time. The supernatant fluid was centrifuged at $105000 \mathrm{~g}$ for $90 \mathrm{~min}$. at $0^{\circ}$. The fat layer was discarded and the remainder of the supernatant fluid pressure-dialysed (at $81 \mathrm{~b} . /$ in. $^{2}$ ) overnight at $4^{\circ}$ against a large volume of solution $C$. After centrifuging at $12000 \mathrm{~g}$ for $10 \mathrm{~min}$. at $0^{\circ}$, this dialysed supernatant solution (termed 'cell sap') was stored at $-18^{\circ}$ or $-70^{\circ}$. It is stable (with respect to activity in the cell-free system) for about a week at $-18^{\circ}$ or several weeks at $-70^{\circ}$, but its activity is lost if it is refrozen.

Pellets from the $105000 \mathrm{~g}$ centrifugation were resuspended in a small volume of ice-cold solution B by gentle hand homogenization in a small Potter homogenizer. To this microsome suspension was added $5 \%(w / v)$ sodium deoxycholate to give a final concentration of $0.5 \%$. After standing on ice for 2 min., the mixture was diluted with $30 \mathrm{vol}$. of ice-cold solution $B$ and the diluted suspension was centrifuged at $105000 \mathrm{~g}$ for $90 \mathrm{~min}$. at $0^{\circ}$. The supernatant solution from this step was discarded and the ribosome pellets were rinsed, suspended in ice-cold $0.5 \mathrm{M}$ sucrose and centrifuged at $12000 \mathrm{~g}$ for $10 \mathrm{~min}$. to remove 'insoluble' material. The resultant supernatant ribosome suspension could be stored at $-18^{\circ}$ for several weeks. Once thawed, ribosomes were not refrozen and reused.

Amino acid-incorporation assay. The complete assay system used had a final volume of $1.0 \mathrm{ml}$. and contained the following (final concentrations): GTP $(0.25 \mathrm{mM})$; ATP (1.0 mM); phosphoenolpyruvate $(5.0 \mathrm{~mm})$; pyruvate kinase $(40 \mu \mathrm{g} . / \mathrm{ml}$.$) ; magnesium acetate (5.0 \mathrm{mM}) ; \beta$-mercaptoethanol (20.0 mM); tris-acetate buffer, $\mathrm{pH} 7 \cdot 7-7 \cdot 8(100 \mathrm{mM})$; $\mathrm{L}-\left[{ }^{14} \mathrm{C}\right]$ phenylalanine of specific activity $9 \mathrm{mc} / \mathrm{m}-\mathrm{mole}$ $(0.135 \mu \mathrm{C})$; the 'other 19 ' amino acids (each $0.05 \mathrm{~mm}$ ); ribosomes equivalent to $2.0 \mathrm{mg}$. of ribosomal protein and a saturating amount of cell sap. The $\mathrm{K}^{+}$concentration in the assay was adjusted to $50 \mathrm{~mm}$ with $\mathrm{KCl}$. Incubations were normally for $40 \mathrm{~min}$. at $37^{\circ}$. At the end of the incubation period the reaction mixtures were chilled and $7.0 \mathrm{ml}$. of $5 \%(w / v)$ trichloroacetic acid was added to each. After standing for at least $20 \mathrm{~min}$. they were centrifuged, the supernatant fluid was discarded, and RNA and lipid were extracted from the pellets as described by Simkin \& Work (1957). The dried protein was dissolved in $98 \%$ formic acid (A.R. grade) to give a final concentration of approx. $6 \mathrm{mg}$. of protein $/ \mathrm{ml}$. An amount equivalent to $1 \cdot 5-2.0 \mathrm{mg}$. of protein was pipetted on to a tared aluminium planchet pretreated with silicone adhesive (cold-cure silastomer; Midlands Silicones Ltd., London, S.W. 1) to prevent curling of the protein films formed on drying under vacuum. The dried samples were weighed, then counted in a thin end-window Geiger-Müller counter. After corrections to 
zero thickness (Calvin, Heidelberger, Reid, Tolbert \& Yankwich, 1949), for counter background and zero-time assay (ribosomes held at $0^{\circ}$ for $40 \mathrm{~min}$. in the presence of ${ }^{14} \mathrm{C}$-labelled amino acid for $40 \mathrm{~min}$.), the results were expressed as counts $/ \mathrm{min}$. $/ 2 \mathrm{mg}$. of ribosomal protein, unless otherwise indicated. Alternatively, in some of the later experiments, the assays were scaled down to a final volume of $0.25 \mathrm{ml}$. and the procedure for radioactivity estimation after incubation was as follows: $0.25 \mathrm{ml}$. of $\mathrm{N}-\mathrm{NaOH}$ containing an excess of unlabelled amino acids was added to each assay tube. After standing for $60 \mathrm{~min}$. at room temperature, the protein was precipitated with $0.5 \mathrm{ml}$. of $30 \%$ $(w / v)$ trichloroacetic acid, filtered on to an Oxoid membrane (Oxo Ltd., London), washed twice with cold 5\% trichloroacetic acid and once each with $5 \%$ trichloroacetic acid at $90^{\circ}$ and with diethyl ether-ethanol $(2: 1, \mathrm{v} / \mathrm{v})$. The dry membrane was glued to an aluminium planchet and counted in a Nuclear-Chicago low-background counter (counting efficiency $16 \%$ ). The results were expressed as counts/min./mg. of ribosomal protein, unless otherwise stated.

Preparation of $E M C$-virus $R N A$ from crystalline virus. Growth, purification and crystallization of EMC virus were as described by Faulkner, Martin, Sved, Valentine \& Work (1961). Crystalline virus was stored in PBS at $-70^{\circ}$ until required. To a freshly thawed crystalline virus suspension (approx. $2 \mathrm{mg}$. of virus $/ \mathrm{ml}$.) were added $5 \%(\mathrm{w} / \mathrm{v})$ deoxy cholate and $20 \mathrm{~mm}-\mathrm{EDTA}, \mathrm{pH} 7 \cdot 2$, to give final concentrations of $0.5 \%$ and $1 \mathrm{mM}$ respectively (Ellem \& Colter, 1961). The suspension was equilibrated at $45^{\circ}$; an equal volume of freshly redistilled water-saturated phenol at $45^{\circ}$ was added and the mixture allowed to stand with occasional mixing for $10 \mathrm{~min}$. at $40-45^{\circ}$. After cooling to $0^{\circ}$ the mixture was centrifuged at $2300 \mathrm{~g}$ for $15 \mathrm{~min}$. at $4^{\circ}$ and the aqueous layer removed. The phenol layer was re-extracted with $0.5 \mathrm{vol}$. of ice-cold water. The combined aqueous layers were mixed with 2 vol. of ethanol containing $2 \%(w / v)$ of potassium acetate and after $1 \mathrm{hr}$. at $0^{\circ}$ the mixture was centrifuged at $2300 \mathrm{~g}$ for $10 \mathrm{~min}$. at $0^{\circ}$. The RNA pellet was washed by very gentle resuspension in ethanol-140 mM- $\mathrm{NaCl}(2: 1, \mathrm{v} / \mathrm{v})$ in a loose-fitting Dounce homogenizer. After recentrifugation as above, the pelleted material was stored at $-70^{\circ}$.

For use in the cell-free system, the RNA was thawed, dissolved in distilled water to give a final concentration of approx. $1 \mathrm{mg} . / \mathrm{ml}$. and used immediately. The concentration of the RNA was estimated spectrophotometrically, $E_{260}^{1 \mathrm{~cm}}$. for $1 \mu \mathrm{g}$. of $\mathrm{RNA} / \mathrm{ml}$. being taken as $0 \cdot 025$.

Preparation of Krebs-cell ribosomal RNA. Ribosomal RNA was prepared from Krebs-cell ribosomes by the guanidinium chloride method of Cox \& Arnstein (1963) with the modification (R. A. Cox, personal communication) that the RNA, after precipitation, was twice redissolved in $6 \mathrm{M}$-guanidinium chloride at room temperature and then precipitated with $0.5 \mathrm{vol}$. of ethanol at $-18^{\circ}$, before being dissolved in water.

Krebs-cell $s-R N A$. RNA was extracted from Krebs cells by the method of Allen, Glassman \& Schweet $(1960 a, b)$ and the s-RNA separated from the bulk RNA according to the $\left(\mathrm{NH}_{4}\right)_{2} \mathrm{SO}_{4}$-fractionation procedure of Littauer \& Eisenberg (1959).

Estimation of ATP in Krebs cells. Cells were extracted with $\mathrm{N}-\mathrm{HClO}_{4}$ and the neutralized supernatant solutions were assayed for ATP by the hexokinase method (Kornberg, 1955).

\section{RESULTS}

Characteristics of the Krebs-cell ribosome-cell sap systems. The characteristics of the ribosome-cell sap systems of the type used throughout these studies are shown in Fig. 1 and Tables 1 and 2 . In these systems amino acid incorporation ceases after approx. $30 \mathrm{~min}$. at $37^{\circ}$ (Fig. 1). It shows a linear dependence on ribosome concentration in the presence of saturating amounts of cell sap. For a given concentration of ribosomes, however, incorporation is dependent on the cell sap concentration up to that saturating level (Table 1). Results of this type were obtained whether the total incorporation observed was high or low. The systems show typical $\mathrm{pH}$ and $\mathbf{M g}^{2+}$ concentration optima (Table 2) and a dependence on ATP and an ATP. generating system. Insensitivity to deoxyribonuclease treatment indicates the absence of any requirement for continuing DNA-mediated m-RNA synthesis. No stimulation of incorporation was observed on the addition of Krebs-cell s-RNA to any of these systems whether assayed in the presence or absence of EMC-virus RNA. It should be noted that throughout this work total incorporation rather than rate of incorporation was measured. Changes in activity therefore refer to changes in total incorporation, although, of course, the rate of incorporation may also be changing.

Effect of storage of Krebs cells at $-70^{\circ}$. In some of the experiments described below, it proved convenient to store cells overnight at $-70^{\circ}$ before isolation of the ribosome and cell-sap fractions. The results of a number of control experiments

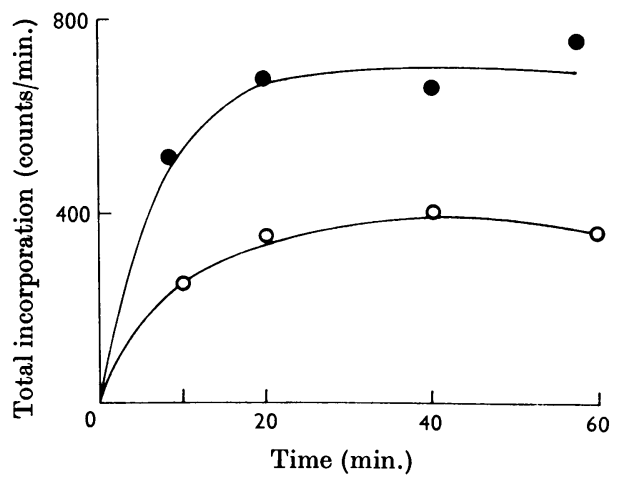

Fig. 1. Time-course of amino acid incorporation. Assays were as described in the Materials and Methods section, $2 \mathrm{mg}$. of ribosomal protein and $3 \mathrm{mg}$. of cell-sap protein being used in each assay. Systems were from: cells washed at room temperature in TBS, then incubated for $4.25 \mathrm{hr}$. at $37^{\circ}$ in Earle's medium; $O$, cells washed at room temperature in TBS. 
Table 1. Characteristics of the Krebs-cell ribosomecell sap system

The complete system contained ribosomes equivalent to $2 \mathrm{mg}$. of ribosomal protein and $3 \mathrm{mg}$. of cell-sap protein. $\mathrm{DL}-\left[{ }^{14} \mathrm{C}\right]$ Leucine $\left(7 \cdot 2 \mathrm{mc} / \mathrm{m}\right.$-mole) or $\mathrm{L}-\left[{ }^{14} \mathrm{C}\right]$ valine $(6 \cdot 5 \mathrm{mc} /$ m-mole) was substituted for $\mathrm{L}-\left[{ }^{14} \mathrm{C}\right]$ phenylalanine where indicated. Results are from duplicate experiments and are corrected relative to a value of 760 counts $/ \mathrm{min}$. for the complete system containing phenylalanine $(0 \cdot 135 \mu \mathrm{c})$. The composition of the complete system is given in the Materials and Methods section.

Total

incorporation (counts/min.

\section{Assay system}

Complete system

assay)

Complete system minus cell sap

Complete system with $1 \mathrm{mg}$. of cell-sap protein

Complete system with $2 \mathrm{mg}$. of cell-sap

protein

Complete system with $4 \mathrm{mg}$. of cell-sap

protein

Complete system minus ribosomes

760

80

550

700

700

360

protein

Complete system with $1.5 \mathrm{mg}$. of ribo-

somal protein

Complete system with $2.5 \mathrm{mg}$. of ribo-

somal protein

Complete system assayed with $\mathrm{DL}-\left[{ }^{14} \mathrm{C}\right]$.

leucine

Complete system assayed with L- $\left[{ }^{14} \mathrm{C}\right]$.

valine

Complete system minus 'other 19' amino acids

Complete system minus ATP and ATP. generating system

Complete system plus deoxyribonuclease

Complete system plus Krebs-cell s-RNA

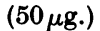

Complete system plus Krebs-cell s-RNA

(200 $\mu \mathrm{g}$.)
925

1340

840

350

50

760

740

710

with cells preincubated under a variety of conditions showed that storage of cells in this way did not significantly alter the activities of the ribosomecell sap systems subsequently isolated from them.

Variation in the amino acid-incorporation activity of ribosome-cell sap systems from differently pretreated cells. Ribosome-cell sap systems prepared from cells that, on being harvested from mice, were washed rapidly in TBS or PBS at $0^{\circ}$ (termed 'coldwashed TBS or PBS cells') supported high levels of incorporation (Table 3). Those prepared from cells washed at room temperature $\left(\mathbf{1 8}-\mathbf{2 2}^{\circ}\right.$ ) ('warmwashed TBS or PBS cells') were one-third to onehalf as active. Further incubation of warm-washed TBS cells in TBS or PBS at $37^{\circ}$ for $30 \mathrm{~min}$. ('warm-

Table 2. Effect of $\mathrm{pH}$ and $\mathrm{Mg}^{2+}$ concentration on amino acid incorporation in the ribosome-cell sap systems

Complete systems containing ribosomes equivalent to $2 \mathrm{mg}$. of ribosomal protein and $5 \mathrm{mg}$. of cell-sap protein were used throughout. Assays carried out between $\mathrm{pH} 7 \cdot 4$ and 8.3 were $100 \mathrm{mM}$ with respect to tris-acetate buffer. Those performed between $\mathrm{pH} 6.6$ and $7 \cdot 4$ were $20 \mathrm{~mm}$ with respect to tris-maleate-KOH buffer (the quantity of $\mathrm{K}^{+}$ added in the form of $\mathrm{KCl}$ to each assay was adjusted for the $\mathrm{K}^{+}$concentration of the buffer solution). The composition of the complete system is given in the Materials and Methods section.

\begin{tabular}{|c|c|c|}
\hline $\begin{array}{l}\text { Concn. of } \\
\mathrm{Mg}^{2+}(\mathrm{m} \mathrm{M})\end{array}$ & $\mathrm{pH}$ & $\begin{array}{l}\text { Total } \\
\text { incorporation } \\
\text { (counts/min./ } \\
2 \mathrm{mg} \text {. of ribo- } \\
\text { somal protein }\end{array}$ \\
\hline 2 & $7 \cdot 8$ & 320 \\
\hline 5 & $7 \cdot 8$ & 760 \\
\hline $7 \cdot 5$ & $7 \cdot 8$ & 695 \\
\hline 10 & $7 \cdot 8$ & 640 \\
\hline 12 & $7 \cdot 8$ & 480 \\
\hline 5 & $6 \cdot 6$ & 550 \\
\hline 5 & $7 \cdot 0$ & 750 \\
\hline 5 & $\begin{array}{c}7 \cdot 4 \\
\text { (tris-maleate buffer) }\end{array}$ & 820 \\
\hline 5 & $\begin{array}{c}7 \cdot 4 \\
\text { (tris-acetate buffer) }\end{array}$ & 900 \\
\hline 5 & $7 \cdot 6$ & 930 \\
\hline 5 & $7 \cdot 8$ & 960 \\
\hline 5 & $8 \cdot 0$ & 650 \\
\hline 5 & $8 \cdot 3$ & 200 \\
\hline
\end{tabular}

Table 3. Effect of preincubation of cells on the ribosome and cell-sap fractions

Each system contained an amount of ribosomes equivalent to $2 \mathrm{mg}$. of ribosomal protein and a saturating amount of cell sap (5 mg. of cell-sap protein/assay). The composition of the complete system is given in the Materials and Methods section. Details of washing procedure and preincubation of cells are given in the Results section.

\begin{tabular}{|c|c|c|}
\hline $\begin{array}{l}\text { Source of } \\
\text { ribosomes }\end{array}$ & $\begin{array}{l}\text { Source of } \\
\text { cell sap }\end{array}$ & $\begin{array}{c}\text { Total } \\
\text { incorporation } \\
\text { (counts/min./ } \\
2 \mathrm{mg} \text {. of ribo- } \\
\text { somal protein) }\end{array}$ \\
\hline $\begin{array}{l}\text { Cold-washed } \\
\text { TBS cells }\end{array}$ & $\begin{array}{l}\text { Cold-washed } \\
\text { TBS cells }\end{array}$ & 860 \\
\hline $\begin{array}{l}\text { Cold-washed } \\
\text { TBS cells }\end{array}$ & $\begin{array}{l}\text { Warm-washed pre- } \\
\text { incubated TBS cells }\end{array}$ & 870 \\
\hline $\begin{array}{l}\text { Cold-washed } \\
\text { TBS cells }\end{array}$ & $\begin{array}{l}\text { Warm-washed TBS } \\
\text { cells }\end{array}$ & 878 \\
\hline $\begin{array}{l}\text { Warm-washed } \\
\text { TBS cells }\end{array}$ & $\begin{array}{l}\text { Warm-washed TBS } \\
\text { cells }\end{array}$ & 358 \\
\hline $\begin{array}{l}\text { Warm-washed pre- } \\
\text { incubated TBS }\end{array}$ & $\begin{array}{l}\text { Warm-washed TBS } \\
\text { cells }\end{array}$ & 40 \\
\hline
\end{tabular}

incorporation (counts/min./ $2 \mathrm{mg}$. of ribo860

Cold-washed

Warm-washed preincubated TBS cells

Warm-washed TBS

Warm-washed TBS cells 
washed preincubated TBS or PBS cells') yielded systems of very low activity. The results of an experiment in which each of the ribosome preparations from these differently pretreated cells was assayed with saturating amounts of a single cell-sap fraction and saturating amounts of each of the cell-sap fractions were assayed with a single ribosome fraction are presented in Table 3. Clearly, the lower activity of the systems from warmwashed and warm-washed preincubated cells resulted from a lowered activity of the ribosome fractions. This decrease in ribosomal activity observed on preincubation of cells in a simple buffered salts medium is referred to below as the 'depression' phenomenon.

The activity of ribosomes from cold-washed and warm-washed cells is also time-dependent, e.g. ribosomes from cells held for $3 \mathrm{hr}$. at $0^{\circ}$ in TBS displayed about one-half the activity of ribosomes from cells harvested and washed rapidly in the cold. To obtain reproducible results it was therefore essential to keep the time taken for harvesting and washing cells reasonably constant.

The recovery phenomenon. Warm-washed and warm-washed preincubated TBS cells, which would yield ribosomes with low activity, were incubated for various times at $37^{\circ}$ in Earle's medium, and the ribosomes isolated and assayed with a single cellsap fraction. Within $20 \mathrm{~min}$. incubation in Earle's medium, the cells yielded ribosomes that were

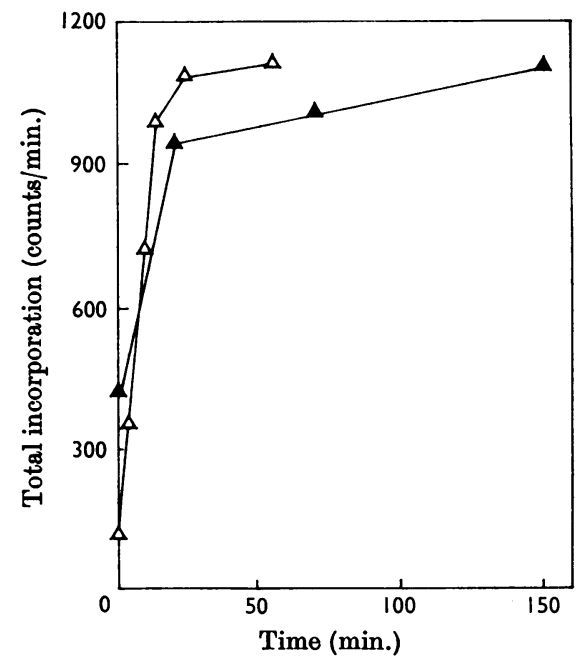

Fig. 2. Time-course of 'recovery' phenomenon. Warmwashed TBS cells $(\Delta)$ and warm-washed preincubated TBS cells $(\Delta)$ were incubated for the times indicated at $37^{\circ}$ in Earle's medium. Ribosomes were prepared and assayed as described in the Materials and Methods section with cell sap from zero-time cells.

again capable of supporting a high level of incorporation in the cell-free system (Fig. 2). To establish the factors necessary for this 'recovery' to occur, cells washed at room temperature in TBS were incubated at $37^{\circ}$ in a variety of modified Earle's media and the ribosomes from them were assayed as indicated in Table 4. Clearly, neither $\mathrm{Ca}^{2+}$ and $\mathrm{Mg}^{2+}$ nor sodium hydrogen carbonate is essential for recovery, but glucose is. The results of Expt. 2 in Table 4 also show that the depression phenomenon occurs on incubation of cells in Earle's medium minus glucose, as well as in the less complex TBS medium.

Basis of the depression and recovery phenomena. Having defined the conditions necessary for the

\section{Table 4. Requirements for the 'recovery' phenomenon}

Ribosomes equivalent to $2 \mathrm{mg}$. of ribosomal protein were used in each assay. All assays in Expt. 1 were carried out with cell sap from cells pretreated for $20 \mathrm{~min}$. at $37^{\circ}$ in pseudo-Earle's medium, and in Expt. 2 with cell sap from cold-washed cells. The compositions of the incubation media are given in the Materials and Methods section.

Total incorporation (counts/min./2 mg. of ribosomal protein)

\section{Pretreatment of cells from which \\ ribosomes were isolated}

Expt. 1. Cells were washed at room temperature in TBS then
(a) incubated for $20 \mathrm{~min}$. at $37^{\circ}$ in Earle's medium

(b) incubated for $20 \mathrm{~min}$. at $37^{\circ}$ in pseudo-Earle's medium

(c) incubated for $20 \mathrm{~min}$. at $37^{\circ}$ in pseudo-Earle's medium minus $\mathrm{Ca}^{2+}$ and $\mathrm{Mg}^{2+}$

(d) incubated for $20 \mathrm{~min}$. at $37^{\circ}$ in pseudo-Earle's medium minus $\mathrm{NaHCO}_{3}$

(e) incubated for $20 \mathrm{~min}$. at $0^{\circ}$ in Earle's medium

Expt. 2 Cells were washed at room temperature in TBS then
(a) incubated for $20 \mathrm{~min}$. at $37^{\circ}$ in Earle's medium
(b) held at $0^{\circ}$ for $20 \mathrm{~min}$. in Earle's medium
(c) incubated for $20 \mathrm{~min}$. at $37^{\circ}$ in Earle's medium minus glucose

$\begin{array}{cc}\text { Assayed with } & \text { Assayed with } \\ \mathbf{3} \text { mg. of } & 5 \text { mg. of } \\ \text { cell-sap } & \text { cell-sap } \\ \text { protein } & \text { protein }\end{array}$

960

1080

1060

1200

880

1100

960

1050

500

500

700

550

300

295 
Table 5. Effect of actinomycin $D$ on the 'depression' and 'recovery' phenomena

Cells were harvested, washed in PBS at $0^{\circ}$, suspended in Earle's medium at $2 \times 10^{7} \mathrm{cells} / \mathrm{ml}$. and divided into two batches. Actinomycin D $\left(5 \mu \mathrm{g} . / \mathrm{ml}\right.$.) was added to one batch and both were left overnight at $4^{\circ}$. They were then incubated for $1 \mathrm{hr}$. at $37^{\circ}$ and washed twice in PBS and once in TBS at room temperature. A third of each batch was stored as packed cells at $-70^{\circ}$ (warm-washed TBS cells \pm actinomycin D). Another third of each batch was incubated at $2 \times 10^{7} \mathrm{cells} / \mathrm{ml}$. in TBS \pm actinomycin $\mathrm{D}$ for $40 \mathrm{~min}$. at $37^{\circ}$. The final third was resuspended in Earle's medium \pm actinomycin $D$ at $2 \times 10^{7}$ cells $/ \mathrm{ml}$. and incubated for $40 \mathrm{~min}$. at $37^{\circ}$. Ribosomes from all six batches were prepared and assayed \pm saturating amounts of EMC-virus RNA with cell sap from non-actinomycin D-treated cells. The alternative scaled-down amino acid-incorporation procedure was used (see the Materials and Methods section), with DL-[14 C]leucine (12 mc/m-mole).

Source of ribosomes

Warm-washed TBS cells

Warm-washed preincubated TBS cells

Warm-washed TBS cells incubated in Earle's medium

Warm-washed TBS cells (+actinomycin D)

Warm-washed preincubated TBS cells (+actinomycin D)

Warm-washed TBS cells incubated in Earle's medium

(+actinomycin D)
Total incorporation (counts/min./mg. of ribosomal protein)

$\begin{array}{ccc}\begin{array}{c}\text { (counts/min./mg. of } \\ \text { ribosomal protein) }\end{array} & \begin{array}{c}\text { Percentage of } \\ \text { warm-washed } \\ \text { TBS-cell }\end{array} \\ \text { No RNA } & \begin{array}{c}\text { RNA-virus } \\ \text { ribosomes } \\ \text { (no RNA) }\end{array} & \begin{array}{c}100 \\ 618\end{array} \\ 211 & 1678 & 34 \cdot 1 \\ 1396 & 1185 & 284.9 \\ 376 & 1724 & 100 \\ 132 & 805 & 35 \cdot 1 \\ 1103 & 2709 & 293 \cdot 4\end{array}$

production of ribosomes capable of supporting different levels of incorporations, an attempt was made to identify the factors or factor responsible for these differences.

In the absence of any evidence for gross structural changes in the ribosomes or ribosomal RNA it seemed possible that the differing activities of the ribosome preparations might reflect differences in their m-RNA content. To investigate this possibility the effect of actinomycin $D, a$ known inhibitor of DNA-directed RNA synthesis (Goldberg, Rabinowitz \& Reich, 1962; Hurwitz, Furth, Malamy \& Alexander, 1962), on the recovery phenomenon was studied and the m-RNA contents of the highand low-activity ribosomes were compared.

The results of the actinomycin $D$ experiment are shown in Table 5. The presence of the drug during preincubation of the cells, whether in the presence or absence of glucose, lowers the activity of the isolated ribosome fractions compared with controls. However, the general pattern of depression and recovery was unaffected. Since actinomycin D in the concentrations used here is known to inhibit 97-98\% of all RNA synthesis in Krebs cells (Horton, Liu, Martin \& Work, 1966), it seems unlikely that depression and recovery depend on the breakdown and synthesis of RNA.

Since most of the experimental criteria for m-RNA are rather arbitrary, it is difficult to measure m-RNA directly. However, the ability of an RNA preparation to stimulate amino acid incorporation in the cell-free system may be taken as some measure of its messenger content.
Table 6. Stimulation of amino acid incorporation in the reticulocyte ribosome-pH5 enzyme system by Krebs-cell 'ribosomal' RNA

The rabbit-reticulocyte light-ribosome assay system (Armstein et al. 1964) was used with $0.25 \mathrm{mg}$. of reticulocyte ribosomes and $1.0 \mathrm{~m} \mu$ mole of $\mathrm{DL}-\left[{ }^{14} \mathrm{C}\right]$ leucine $(160 \mathrm{mc} / \mathrm{m}$ mole) per assay. The composition of the assay medium is given in the Materials and Methods section.

Total

RNA added

None incorporation (counts/min.)

$11 \mu \mathrm{g}$. of reticulocyte ribosomal RNA

818

$22 \mu \mathrm{g}$. of reticulocyte ribosomal RNA

$12 \mu \mathrm{g}$. of RNA from ribosomes of cold-

1172

1500

1038

washed TBS cells

$24 \mu \mathrm{g}$. of RNA from ribosomes of cold-

1201

washed TBS cells

$12 \cdot 25 \mu \mathrm{g}$. of RNA from ribosomes of warmwashed preincubated TBS cells

24.5 $\mu$ g. of RNA from ribosomes of warmwashed preincubated TBS cells

1193

1303

RNA was therefore isolated from ribosomes of warm-washed preincubated and cold-washed cells by the guanidinium chloride method of Cox \& Arnstein (1963). When analysed in the analytical ultracentrifuge the two preparations gave identical patterns with only the two normal ribosomal components visible. There was no evidence for any degradation of the RNA. The ability of these preparations to stimulate amino acid incorporation was compared in a reticulocyte ribosome-pH5 
enzyme system prepared by the standard method of Arnstein, Cox \& Hunt (1964). Both preparations produced appreciable stimulations compared with reticulocyte ribosomal RNA (Table 6). Assuming these stimulations to be a true measure of m-RNA content, it would appear that there is little difference between the ribosomes of warm-washed preincubated and cold-washed TBS cells in this respect.

Further circumstantial evidence against any variation in the m-RNA content of these different ribosome preparations was provided by the results of experiments to determine their polysome content. Preliminary studies involving sucrose-densitygradient analysis of ribosomes from cold-washed and warm-washed preincubated TBS cells have not, within the limitations of the technique, revealed differences in polysome content.

Variation in the ATP content of cells during depression and recovery. Laws \& Stickland (1963) found that washing Ehrlich mouse ascites-tumour cells profoundly altered the ability of these cells to synthesize ATP. The ATP content of the differently preincubated Krebs cells was therefore measured. The results presented in Table 7 show that incubation of warm-washed TBS cells at $37^{\circ}$ in the absence of glucose produces a rapid fall in the intracellular ATP content. On the addition of glucose and further incubation, the ATP content of such cells 'recovers' rapidly to the control level. Samples of the cells incubated as shown in Table 7 were used for ribosome preparation and the activity of the ribosomes was assayed with a single cell-sap fraction. The pattern of 'depression' and 'recovery' of ribosomal activity, as shown in Table 7, follows the pattern of change in ATP content in Table 7. This, however, does not prove a direct relationship between the intracellular ATP content and the ribosomal activity, but merely indicates that environmental conditions producing changes in the intracellular ATP content also produce changes in the activity of the ribosomes, in the same direction.

Stimulation of amino acid incorporation in the cell-free system by $E M C$-virus $R N A$. It might reasonably be expected that ribosomes deficient in m-RNA would respond well to the addition of exogenous messenger. It was therefore decided to compare the responses of the different ribosome preparations described above to EMC-virus RNA and polyU.

The EMC-virus RNA used throughout these studies was isolated from crystalline virus (Faulkner et al. 1961) by a modified phenol extraction technique. It consisted of approx. $50 \%$ of non-degraded $35 \mathrm{~s}$ material and was highly infective when assayed in mice $\left(10^{7} \mathrm{LD}_{50}\right.$ units/mg. of $\left.\mathrm{RNA}\right)$ or by a plaque assay technique $\left(10^{8}\right.$ plaque-forming units $/ \mathrm{mg}$. of RNA).

Both EMC-virus RNA and polyU stimulate amino acid incorporation in the high- and lowactivity ribosome-cell sap systems described above (Table 5 and Fig. 3). Similar stimulations were not observed with total Krebs-cell RNA, Krebs-cell s-RNA or degraded ( $<4 \mathrm{~s})$ EMC-virus RNA. In accord with results obtained with other cell-free systems and ribonucleic acids (Arnstein, Cox \& Hunt, 1962 ; Davies, Gilbert \& Gorini, 1964 ; Szer \& Ochoa, 1964), the stimulation by EMC-virus RNA and poly $\mathbf{U}$ both show sharp and distinct $\mathrm{Mg}^{2+}$

\title{
Table 7. Variation in ATP content and the activity of the ribosomes in differently preincubated Krebs cells
}

\begin{abstract}
Warm-washed TBS cells were incubated as shown below at a concentration of $2 \times 10^{7}$ cells $/ \mathrm{ml}$. The glucose concentration used is that present in Earle's medium. Samples $(0.5 \mathrm{ml}$.) were taken at the end of the incubations for assay of the ATP content as described in the Materials and Methods section. The bulk of the cells were used to prepare ribosomes that were then assayed with $\mathrm{DL}-[1-14 \mathrm{C}]$ leucine $(12 \mathrm{mc} / \mathrm{m}$-mole $)$ in the scaled-down amino acid-incorporation assay (see the Materials and Methods section). Each tube contained 500 $\mu$ g. of ribosomal
\end{abstract} protein and $1.14 \mathrm{mg}$. of cell-sap protein.

Treatment of cells

In TBS at $0^{\circ}$ for $60 \mathrm{~min}$.

In TBS at $37^{\circ}$ for $20 \mathrm{~min}$., then at $0^{\circ}$ for $40 \mathrm{~min}$.

In TBS at $37^{\circ}$ for $40 \mathrm{~min}$., then at $0^{\circ}$ for $20 \mathrm{~min}$.

In TBS $+2 \mathrm{mg}$. of glucose $/ \mathrm{ml}$. at $37^{\circ}$ for $40 \mathrm{~min}$., then at $0^{\circ}$

for $20 \mathrm{~min}$.

In TBS at $37^{\circ}$ for $20 \mathrm{~min}$., then in TBS $+2 \mathrm{mg}$. of glucose $/ \mathrm{ml}$. for $20 \mathrm{~min}$. at $37^{\circ}$, followed by $20 \mathrm{~min}$. at $0^{\circ}$

In TBS at $37^{\circ}$ for $40 \mathrm{~min}$., then in TBS $+2 \mathrm{mg}$. of glucose $/ \mathrm{ml}$. for $20 \mathrm{~min}$. at $37^{\circ}$
Total

incorporation (counts/min.)

ATP content mg. of ribo-

( $\mu \mathrm{g} . / 10^{7}$ cells) somal protein)

$30 \cdot 2$

$8 \cdot 9$

$17 \cdot 0$

$45 \cdot 4$

$49 \cdot 8$

590

193

196

1524

$45 \cdot 6$

2944

1564 


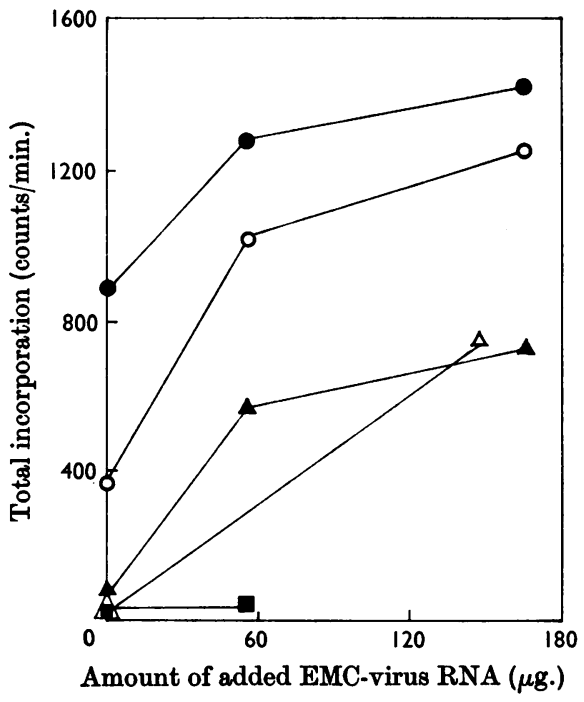

Fig. 3. Comparison of the response of ribosomes from differently preincubated cells to EMC-virus RNA. Each system contained ribosomes equivalent to $2 \mathrm{mg}$. of ribosomal protein and a saturating amount of cell sap (5 mg. of cell-sap protein/assay). EMC-virus RNA in the amounts shown was added to the following cell-free systems: $\bullet$, cold-washed TBS-cell system; $O$, warm-washed TBS-cell system; $\Delta$, warm-washed preincubated TBS/cell system; $\triangle$, system of warm-washed preincubated TBS-cell ribosomes and cold-washed TBS-cell cell sap; $\square$, cold-washed TBS-cell cell sap (i.e. as for but minus ribosomes).

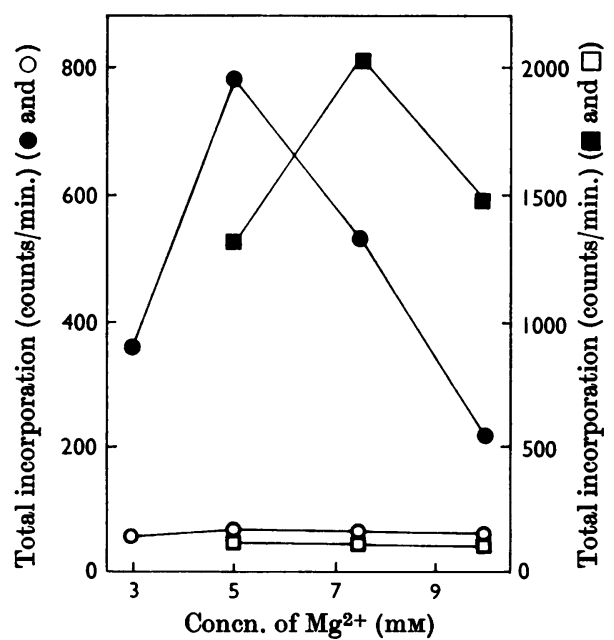

Fig. 4. $\mathrm{Mg}^{2+}$ concentration dependence of the response of cell-free systems to EMC-virus RNA and to polyU. Systems contained warm-washed preincubated TBS-cell ribosomes equivalent to $2 \mathrm{mg}$. of ribosomal protein and saturating amounts of cold-washed TBS-cell cell sap (5 mg. of cell-sap protein/assay): $\square$, no polyU; $\square,+20 \mu \mathrm{g}$. of polyU; $O$, no EMC-virus RNA; 0, +150 $\mu$ g. of EMC-virus RNA. concentration optima (Fig. 4). With a depressed ribosome system, it was shown that approx. $60 \%$ of the total incorporation after stimulation by EMC-virus RNA was into supernatant protein and that at least $60 \%$ of this sedimented in a sucrose density gradient with a velocity of $2-8 \mathrm{~s}$ with a broad peak at $2 \cdot 6 \mathrm{~s}$ (I. M. Kerr, M. G. Hamilton \& T. S. Work, unpublished results). Thus it appears that a significant proportion of the amino acid incorporated in response to EMC-virus RNA is incorporated into high-molecular-weight polypeptide.

As shown in Fig. 3 and Table 5, the absolute stimulation of amino acid incorporation observed in response to saturating amounts of EMC-virus RNA does not differ widely for ribosomes of very different activities from cold-washed, warm-washed and warm-washed preincubated TBS cells. Moreover, there was no evidence to indicate that any factor other than the ribosome concentration was limiting in the final level of incorporation observed with the high-activity ribosomes from cold-washed cells in the presence of saturating amounts of EMCvirus RNA. Similar results have been obtained with polyU in place of EMC-virus RNA. The small amount of RNA required to saturate the system, and the fact that the levels of incorporation achieved with a high-activity system saturated with EMC-virus RNA always considerably exceed that observed with a similarly saturated low-activity system, suggests that only a fraction of the ribosomes is capable of responding to the added RNA. Further, this fraction appears to be relatively, if not completely, unaffected by the depression and recovery phenomena (Fig. 3 and Table 5).

Further tentative evidence in favour of a catalytic turnover of EMC-virus RNA through a limited number of ribosomes is provided by the kinetics of the amino acid incorporation after stimulation by EMC-virus RNA (Fig. 5). Curve $E$ in Fig. 5, which represents the time-course of incorporation stimulated by EMC-virus RNA, shows that there is virtually no stimulation at $5 \mathrm{~min}$. A similar time lag has been reported for the tobacco-mosaic-virusRNA-Escherichia coli cell-free system (Barondes \& Nirenberg, 1962) and for polyU-stimulated incorporation in the rabbit-reticulocyte ribosomal system (Arlinghaus \& Schweet, 1962). The reason for this lag is not known, but it may represent the time required for the attachment of EMC-virus RNA to the ribosomes and the synthesis of peptide chains that are sufficiently long to be precipitated in the assay procedure used. At $10 \mathrm{~min}$., but not at $40 \mathrm{~min}$., the system was saturated by $60 \mu \mathrm{g}$. of EMC-virus RNA (curves $B$ and $C$ in Fig. 5), suggesting that EMC-virus RNA in excess of $60 \mu \mathrm{g}$. added at zero time functions by maintaining incorporation over a longer period rather than by

Bioch. 1966, 98 


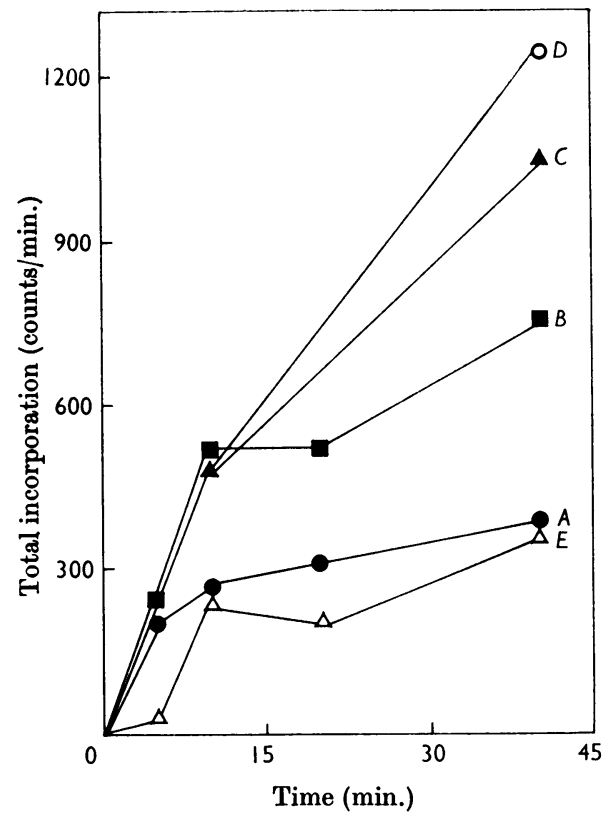

Fig. 5. Kinetics of stimulation by EMC-virus RNA. Each assay contained warm-washed TBS-cell ribosomes equivalent to $2 \mathrm{mg}$. of ribosomal protein and a saturating amount of cold-washed TBS-cell cell sap (5mg. of cell-sap protein/ assay) : $\bullet$, no added RNA (curve $A$ ); $\square, 60 \mu$ g. of EMC-virus RNA at zero time (curve $B$ ); $\Delta, 150 \mu \mathrm{g}$. of EMC-virus RNA at zero time (curve $C$ ); $0,150 \mu \mathrm{g}$. of EMC-virus RNA at zero time +further $60 \mu \mathrm{g}$. at $10 \mathrm{~min}$. (curve D); $\Delta$, net stimulation due to $60 \mu \mathrm{g}$. of EMC-virus RNA (curve $E$ ).

increasing the initial rate. It seemed therefore that optimum stimulation by EMC-virus RNA might be achieved by successive additions throughout the incubation period. A comparison of curves $C$ and $D$ in Fig. 5 shows that the extent of incorporation can indeed be increased in this way.

The low-activity ribosomes produced by preincubation of the cells as described above gave a several-fold greater absolute response to EMC-virus RNA than did Krebs-cell ribosomes preincubated under the conditions of the amino acid-incorporation assay, as described by Nirenberg \& Matthaei (1961).

\section{DISCUSSION}

Experiments with actinomycin D (Staehelin, Wettstein \& Noll, 1963) have shown that the average half-life of m-RNA in mammalian cells is much greater than in bacteria (Levinthal, Keynan \& Higa, 1962). In view of this it seemed likely that a mechanism might exist for controlling protein synthesis at some level besides that of gene trans- cription. Such a mechanism could operate at the ribosome level.

We have demonstrated that a cell-free ribosomecell sap preparation from Krebs cells shows remarkable variability in its protein-synthesizing ability according to the previous history of the cells. This variability cannot be attributed entirely to a variation in the m-RNA content of the system. Recovery of ribosome activity when glucosestarved cells were reincubated in glucose was much too rapid to be attributed to messenger synthesis and in any case 'recovery' occurred in the presence of actinomycin $D$. The presence of extractable 'messenger' in an inactive ribosome preparation suggests that lack of messenger is not the explanation of the low activity of the ribosome-cell sap preparations from glucose-starved cells. Our colleague D. C. Dumonde (personal communication: Dumonde, Bitensky, Cunningham \& Chayen, 1965) has found that there is increased lysosomal breakdown when Ehrlich cells are incubated in the absence of glucose and we cannot completely exclude the possibility that fragmented m-RNA is active when extracted and tested in a reticulocyte ribosome system, but we consider this explanation improbable. It seems more likely to us that the m.RNA-ribosome complex can exist in an active or in an inactive state and that in the inactive state the messenger remains in contact with the ribosomes but in a non-functional and 'protected' state. Recent work on reticulocytes and on sea-urchin eggs encourages us in this view. Thus Marks, Burka, Conconi, Perl \& Rifkind (1965) have found that incubation of reticulocytes with sodium fluoride can convert rabbit-reticulocyte ribosomes into an inactive form but that cell recovery occurs promptly if fluoride is removed and glucose is added to the reticulocytes. In this system new messenger certainly cannot be formed as there is no nucleus. It is also relevant that Hultin (1964) showed the conversion of inactive into active ribosomes after fertilization of sea-urchin eggs. This conversion is energy-dependent but does not require messenger synthesis. In this respect the fertilized sea-urchin egg resembles the starved Krebs cell or the fluoride-treated reticulocyte in that it contains a population of ribosomes that can exist in an inactive or in an active form; in all three examples the conversion of the active form appears to be energy-dependent.

These results therefore strongly suggest that in the Krebs cell and in many other cells a mechanism exists for controlling the rate and extent of protein synthesis at the level of the ribosome independently of other control mechanisms that operate at the level of gene transcription. The response of 'in. active' ribosome preparations to added EMC-virus RNA shows that only a portion of the ribosomes 
undergo this active-inactive transformation and that the proportion of EMC-virus-RNA-responsive ribosomes (presumably monomers) does not alter during cell starvation.

The above experiments do not yet provide an adequate basis for the understanding of the depression and recovery phenomena or of the factors controlling the response of ribosomal preparations of different intrinsic activities to EMC-virus RNA. However, from a purely practical point of view, these results are of considerable interest, for any variation in the time or temperature of pretreatment of cells can appreciably alter the activity in vitro of ribosomes subsequently isolated from them. It is therefore essential that in a comparison of the activities of ribosomes from differently pretreated cells the procedures used in the preparation of the cells for ribosomal isolation should be rigidly controlled. These results indicate that the relative amino acid-incorporation activities of ribosome preparations, assayed in the cell-free system, do not necessarily reflect their m-RNA content or that of the cells from which they were isolated, although under certain conditions they may undoubtedly do so. The response of such systems to the addition of exogenous m-RNA in the form of EMC-virus RNA or polyU appears to bear no necessary correlation to their intrinsic activities.

We thank Dr A. J. Morris for assistance in developing the cell-free system. Mr J. Coote provided skilled technical assistance.

\section{REFERENCES}

Allen, E. H., Glassman, E. \& Schweet, R. S. (1960a). J. biol. Chem. 231, 1061.

Allen, E. H., Glassman, E. \& Schweet, R. S. (1960b). J. biol. Chem. 231, 1068.

Arlinghaus, R. \& Schweet, R. S. (1962). Biochem. biophys. Res. Commun. 9, 482.

Arnstein, H. R. V., Cox, R. A. \& Hunt, J. A. (1962). Nature, Lond., 194, 1042.
Arnstein, H. R. V., Cox, R. A. \& Hunt, J. A. (1964). Biochem.J. 92, 648.

Barondes, S. H. \& Nirenberg, M. W. (1962). Science, 138, 810.

Calvin, M., Heidelberger, C., Reid, J. C., Tolbert, B. M. \& Yankwich, P. F. (1949). Isotope Carbon: Techniques in its Measurement and Chemical Manipulation, p. 317. London: Chapman and Hall.

Cox, R. A. \& Arnstein, H. R. V. (1963). Biochem.J. 89, 574.

Davies, J., Gilbert, W. \& Gorini, L. (1964). Proc. nat. Acad. Sci., Wash., 51, 883.

Dumonde, D. C., Bitensky, L., Cunningham, G. J. \& Chayen, J. (1965). Immunology, 90, 25.

Ellem, K. A. O. \& Colter, J. S. (1961). Virology, 15, 113.

Faulkner, D., Martin, E. M., Sved, S., Valentine, R. C. \& Work, T. S. (1961). Biochem. J. 80, 597.

Goldberg, I. H., Rabinowitz, M. \& Reich, E. (1962). Proc. nat. Acad. Sci., Wash., 48, 2094.

Horton, E., Liu, S. L., Martin, E. M. \& Work, T. S. (1966). $J$. molec. Biol. (in the Press).

Hultin, T. (1964). Developmental Biol. 10, 305.

Hurwitz, J., Furth, J. V., Malamy, M. \& Alexander, M. (1962). Proc. nat. Acad. Sci., Wash., 48, 1222.

Kerr, I. M., Martin, E. M., Hamilton, M. G. \& Work, T. S. (1962). Cold Spr. Harb. Symp. quant. Biol. 27, 259.

Kornberg, A. (1955). In Methods in Enzymology, vol. 2, p.497. Ed. by Colowick, S. P. \& Kaplan, N. O. New York: Academic Press Inc.

Laws, J. O. \& Stickland, L. H. (1963). Biochem. J. 87, 520.

Levinthal, C., Keynan, A. \& Higa, A. (1962). Proc. Nat. Acad. Sci., Wash., 48, 1631.

Littauer, U. Z. \& Eisenberg, H. (1959). Biochim. biophys. Acta, 32, 320.

Lowry, O. H., Rosebrough, N. J., Farr, A. L. \& Randall, A. J. (1951). J. biol. Chem. 193, 265.

Marks, P. A., Burka, E. R., Conconi, F. M., Perl, W. \& Rifkind, R. A. (1965). Proc. nat. Acad. Sci., Wash., 53, 1437.

Martin, E. M., Malec, J., Sved, S. \& Work, T. S. (1961). Biochem. J. 80, 585.

Nirenberg, M. W. \& Matthaei, J. H. (1961). Proc. nat. Acad. Sci., Wash., 47, 1588.

Simkin, J. L. \& Work, T. S. (1957). Biochem. J. 65, 307.

Staehelin, T., Wettstein, F. O. \& Noll, H. (1963). Science, 140, 180.

Szer, W. \& Ochoa, S. (1964). J. molec. Biol. 8, 823. 